\title{
Modern methods of the regional development's sustainability assessment and their approbation - the Republic of Tatarstan, for example
}

\author{
Sergey Nikolaevich Kirillov \\ Lomonosov Moscow State University \\ Faculty of Geography \\ Moscow Russia
}

\author{
Sergey Mikhailovich Nikonorov \\ Lomonosov Moscow State University \\ Faculty of Economics \\ Moscow, Russia
}

\author{
Alla Anatolevna Pakina \\ Lomonosov Moscow State University \\ Faculty of Geography \\ Moscow, Russia \\ allapa@yandex.ru
}

\begin{abstract}
Elaboration of integrated development indicators, that take into account economic, environmental and social criteria, is one of the topical issues in the theory and practice of the development sustainability's assessment. The decoupling coefficient, which is widely used in complex sustainability's studies, is one of the indicators, reflecting the dynamics of both economic and environmental parameters. In this paper we investigate the possibility to use the decoupling coefficient to assess trends of regional development on example of one of the most developed regions of Russia - the Republic of Tatarstan. Differentiation of decoupling coefficient values by administrative territorial units of Tatarstan shows the need for further research to substantiate the choice of indicators, reflecting the level of human activities' pressure on the environment, depending on type of environmental management.
\end{abstract}

Keywords - sustainability, assessment, decoupling effect, Volga region, Republic of Tatarstan

\section{INTRODUCTION}

The relevance of a methodology to assess the development's sustainability at the regional level has been repeatedly emphasized in a number of international and national documents. One of the founding document, the "Agenda 21", notify in Chapter 40 that "Commonly used indicators such as the gross national product (GNP) and measurements of individual resource or pollution flows do not provide adequate indications of sustainability. $\cdots$ Indicators of sustainable development need to be developed to provide solid bases for decision-making at all levels and to contribute to a self-regulating sustainability of integrated environment and development systems" [1]. The sustainable development indicators play a critical role also in more recent UN documents, such as "The Future We Want" (2012) and "The 2030 Agenda for Sustainable Development" (2015).

The problem of sustainability's criteria and corresponding integrated indicators has moved to a practical level in recent years. It is evidenced, for example, by the content of the orders of the President of the Russian Federation by the results of the State Council meeting, devoted to the issue of "Environmental development of the Russian Federation for the benefit of future generations" (2016). They are supposed to pay special attention to "the system of sustainable development indicators, the definition of mechanisms for achieving the goals and the gradual solution of the tasks of environmentally sustainable development of the regional territories for the period up to 2030 and for the future up to 2050" [2].

Implementation of the sustainable development's indicators to the process of the national policy making, the strategic state and regions priorities determining and the legislation developing is the most important result of their elaboration. The system of such indicators allows not only to evaluate the results, but also to identify problem points, to take into account the interests of various stakeholders, to improve management decisions. The paper analyzes the results of the Volga regions ranking on the basis of the methods used in modern practice to assess the sustainability of development, taking into account economic, environmental and social aspects. On the example of one of the most economically developed regions - the Republic of Tatarstan - the evaluation method, which is based on the principle of "decoupling" , is tested. 
The comparison of such indicators as industrial production and air emissions increases from stationary sources in the Russian Federation shows their consistency [3]. Growth in production was accompanied by an increase in anthropogenic impact on the environment and conversely. At the same time, the amplitude of the indicators characterizing the volume of air emissions of industrial pollutants from stationary sources was less than the pollution volume of industrial production. The proposed approach can be quite useful in studies of the quality of economic growth.

\section{MATERIALS AND METHODS}

The practice of sustainability assessment, existing today, shows that available sustainability indicators are far from perfect. Among the most popular indicators - such as the Human Development Index (HDI), Index of Adjusted Net Savings, and indicators proposed by WWF: Ecological Footprint and the Living Planet Index. The Economicecological index of Russian regions, as an adaptation of the Index of Adjusted Net Savings to the Russian realities, is very significant for the sustainability assessment methodology [4].

Obviously, an integrated index development is a task of interdisciplinary research that requires the participation of both economists and representatives of natural sciences. The necessity to take into account three groups of factors economic, environmental and social, which have often opposite meanings and different units of measurement, has determined the interest of a wide range of professionals to this activity. In our study we compared a number of regions of the Volga region on the above-mentioned indicators to identify the correlation between them.

The comparative analysis led us to conclude that a system of sustainability's development indicators must be based on the relative indicators, allowing, to the extent possible, to correlate the economic, environmental and social parameters of development. The decoupling indicator, which has been widely used in recent years to assess the "divergence" of economic growth trends and environmental impact, meets these conditions. The principle of decoupling is widely used in complex assessments of development, and many works of both Russian and foreign authors are devoted to its study during last decade [5-7].

Decoupling effect means a discrepancy between the population welfare growth rates and the environmental impact, and the presence of the decoupling effect means that economic growth is accompanied by a decrease in such a pressure of human activity to environment [8]. The decoupling factor is calculated as the ratio of the pollution level and GDP (gross domestic product) in the current period to the baseline:

$$
D_{t}=1-\frac{E P_{t}}{D F_{t}} / \frac{E P_{t-1}}{D F_{t-1}}
$$

where $\mathrm{D}_{\mathrm{t}}-$ decoupling coefficient, $\mathrm{EP}_{\mathrm{t}}$ and $\mathrm{EP}_{\mathrm{t}-1}-$ indicators of environmental impact in the current period to the base period, $\mathrm{DF}_{\mathrm{t}}$ and $\mathrm{DF}_{\mathrm{t}-1}$ - indicators of economic development in the same periods.
The positive value of the decoupling coefficient indicates that the growth rate of the environmental impact is reducing compared to the growth rate of the economy for the same period. The substantial advantage of this approach is the fact that the comparison of economic and environmental results of environmental management does not require the points score, which often equalize some differences in absolute values.

\section{RESULTS AND DISCUSSION}

The integrated indicators allow to rank regions in accordance to a number of criteria and form the basis for policy making decisions. The analysis of the available data showed that, depending on used indicators, the positions of the regions can changing significantly. In our case, the positions of the administrative territorial units of the Volga region on the Environmental-economic index (EEI) [9] and the Ecological Footprint (EF) [10] correlate not only with the ranking data on the Human Development Index (HDI) [11], but also the GRP values (table 1).

TABLE I. SOCIO-ECOLOGICAL AND ECONOMIC CHARACTERISTICS OF THE VOLGA REGIONS

\begin{tabular}{|l|c|c|c|c|}
\hline $\begin{array}{c}\text { Russian Federation } \\
\text { subjects }\end{array}$ & $\begin{array}{c}\text { GRP }^{\text {a }} \\
\text { mln. RR }\end{array}$ & HDI & $\begin{array}{c}\text { EEI, } \\
\text { \% } \\
\text { GRP }\end{array}$ & $\begin{array}{c}\text { EF, } \\
\text { gha } \\
\text { per } \\
\text { capita }\end{array}$ \\
\hline Republic of Mari El & 165531,0 & 0,835 & 35.47 & 4.07 \\
\hline Republic of Tatarstan & 1833214,5 & 0,894 & 19.91 & 4.97 \\
\hline Chuvash Republic & 250408,9 & 0,839 & 33.94 & 3.95 \\
\hline Samara region & 1240319,8 & 0,865 & 9.38 & 5.59 \\
\hline Ulyanovsk region & 301424,7 & 0,843 & 39.79 & 4.46 \\
\hline
\end{tabular}

b. gha - global hectars

The interpretation of the Sustainable Development concept of society through economic growth while reducing environmental risks and improving the quality of life has become particularly relevant after acceptance the concept of "green" economy [12]. Today, this concept is perceived as the basis for the practical implementation of the principles of sustainable development, as evidenced, for example, in the UN document "The Future We Want", which considering the prospects of mankind for the XXI century on the principles of the "green" economy as a basis of the sustainable development [11].

The possibilities to use the methodological approach based on the calculation of the decoupling coefficient were analyzed on example of one of the Volga regions - the Republic of Tatarstan. The region's choice was determined by a number of reasons, among which the most significant aspects are: economical (high level of economic development and diversified structure of the economy), environmental (location in the ecologically significant region of the Volga river basin) and social (high level of inequality in the living standards of the population).

As of 2016, the Republic ranks 6th among all the regions of the Russian Federation in terms of GRP, 3rd in terms of investments in fixed assets, 4th and 5th in terms of agricultural and industrial production, respectively [13]. The Samara 
region is the next in terms of GRP, other regions (out of the considered ones) are significantly inferior to them, characterized by GRP volumes of less than 1 trillion RR.

Analysis of statistical data on the economic development of the region, as well as the associated environmental impact, showed that in the period from 2011 to 2016, the industrial production growth in the Republic was accompanied by an increase in the anthropogenic pressure on the environment, and the rate of this growth varied. GRP growth (in current prices) from 1.31 to 1.94 trillion. RR for the same period was accompanied by an increase in air emissions (from 277.9 to 289.6 thousand tons per year). The total water withdrawal from natural water bodies increased from 767.0 to 879.4 million $\mathrm{m}^{3}$ in the period from 2011 to 2015 [14]. At the same time, the share of polluted waters in the total volume of discharged waters decreased from 479.9 million $\mathrm{m}^{3}$ to 325.5 million $\mathrm{m}^{3}$ between 2011 and 2015 .

Taking into account the industrial character of the Tatarstan economics, the data on air emissions from stationary sources can be used to estimate the effect of decoupling. Since the atmospheric emissions are correlated with the level of industrial development, the structure of the economy and the nature of the prevailing environmental problems, i.e. the level of human activity's pressure in general, this approach can be considered as suitable.

The result $(\mathrm{Dt}=0.25)$ allows to conclude about the presence of decoupling effect in Tatarstan. However it should be noted that a detailed review of the situation confirms the assumption that development trends are formed under the different, sometimes opposite, factors. Thus, despite the increase in air emissions in the Republic of Tatarstan in general, the region is characterized by the decoupling effect due to a significant (almost 40\%) increase in GRP. The same situation in other Volga region - for example, in the Chuvash Republic - is the result of a minor increase in GRP (33\%) with a slight decrease in emissions. In general, the dynamics of emissions in the region is quite uneven: in the Republic of Tatarstan emissions into the air increased in the period from 2011 to 2013, but remained almost unchanged in 2014-2015. Nevertheless, the decoupling effect is inherent for the Republic of Tatarstan also according the data on the water resources use: $\mathrm{Dt}=0.28$.

In order to obtain a detailed picture of the correlation between economic development and environmental pressure trends, we considered changes in the value of decoupling at the level of administrative districts of the Republic. As a result, the following data were obtained for the administrative territorial units (districts) of the Republic of Tatarstan: the value of decoupling coefficient is negative in 12 of 43 districts, and positive - in the remaining 31 districts.

The number of districts, which are characterized by negative values of decoupling coefficient, are: Aznakaevsky, Aksubaevsky, Zainsky, Tetyushsky and some others. The districts differ not only in the prevailing types of environmental management, but also by the nature of the factors that lead to the effect of decoupling. For example, the growth of the Gross Territorial Product (GTP) in the Aznakayevsky district during the period under review, was accompanied by an increase in emissions to the environment and by a significant fluctuation in the costs of environmental protection.

The emissions into atmospheric air in Zainsk district are "in antiphase" to dynamics of GTP at the same period: along with increase of GTP from 27.8 to 32.9 billion RR they increased from 2010 to 2013 and decreased by 2015 [15, 16].

Similar dynamics of indicators both of economic growth and anthropogenic pressure is typical for many districts of the Republic of Tatarstan. At the same time, the coincidence of trends - the increase in emissions with GDP growth - can be accompanied by both the presence or absence of the decoupling effect in different districts. For example, in the Tetyushsky district, GDP growth of $70 \%$ was accompanied by an increase in emissions by 2 times, and such proportion has resulted in a negative value of the coefficient. In contrast, the situation in districts, where the decoupling effect is recorded, is more similar. Thus, in Alekseevsky, Elabuga and a number of other districts GDP growth was accompanied by some reduction of emissions.

The situation in the administrative territorial units of the Republic of Tatarstan differs significantly. This differentiation indicates not only a different level of organization of environment protection activities, including its financing, but also - to a greater extent - the need for further interpretation of the results. Despite the "universality" of the indicator of pollutant emissions into the air as an indicator of environmental pressure, there is a necessary to improve a choice of such indicators: depending on the land use in the region, the dynamics of the area of eroded lands, the forest cover of the territory, the volume of municipal and industrial waste, etc. can be taken as a basic [17].

Zainsky district, mentioned above, can be considered as a typical example: the economy of the district is characterized by the high share of energy and oil production, and processing industry, but the agro-industrial complex is a leading sector of economy. In this regard, such "weak sides" of the economy as a high degree of production assets' wear and a decrease in soil fertility are of particular importance. At the same time, attempts to assess the effect of decoupling on the basis of various indicators are often unproductive due to the extremely weak statistical base (lack of or unreliability of data), but the continuation of such studies seems to be very promising, at least from the point of view of effectiveness of regional environmental management assessment. It is indicated by many authors $[3,5,9]$, analyzing in their works approaches to assessing the sustainability of regional development, taking into account the sectoral characteristics of the economy.

\section{CONCLUSION}

The analysis undertaken in the study allows to consider the decoupling effect from different points of view: as a methodical approach to measure the stability of development, and as a practical application of the considered approach. Modernization of the national economy in accordance to the principles of sustainable development or "green" growth can be implemented only in a case of complex accounting of economic, environmental and social indicators. The revision 
of development strategies at the regional level requires priority attention to the quality of growth, which is fully consistent with the considered methodological approach based on the detection of the decoupling effect is a specific complex task, which, nevertheless, can be solved on the basis of constantly improving statistical base. At the same time, the decoupling indicator can be used not only to reflect trends in the state of environment caused by economic growth, but also the social aspects of development, since the environmental situation significantly affects the quality of life of the population. In addition, the decoupling indicator can be considered in the context of fair distribution of benefits by analogy with the approach used in the work [18]. Economic development's trends of the region can be considered taking into account changes in the nature of production or environmental management in general. From this point of view, the assessments may be based on indicators of social processes, such as employment, the level of social security, etc. It will contribute to recommendations for the development of regional environmental management in accordance with the principles of sustainable development.

\section{Acknowledgment}

The study was carried out with the financial support of the Russian Foundation for Basic Research, project No. 17-0200773 "Theoretical and methodological foundations for sustainable development of Russian regions (on the example of the Volga region)".

\section{References}

[1] Agenda 21. United Nations Sustainable Development. Режим доступа: https://sustainabledevelopment.un.org/content/documents/Agenda21. Дата обращения: 28.01.2018

[2] On ensuring realization of the presidential instructions following the meeting of the State Council of the Russian Federation on 27 December 2016 [Ob obespechenii vypolnenija poruchenij Prezidenta Rossii po itogam zasedanija Gosudarstvennogo soveta RF 27 dekabrja 2016 g.]. Official website of the Government of the Russian Federation. Режим доступа: http://government.ru/orders/selection/404/26407/ Дата обращения: 28.01.2018

[3] Tereshina, M. V., Asaliev, A. M. The manifestation of the decoupling effect in the development of territorial systems of environmental management (on the example of Krasnodar region) [Projavlenie jeffekta dekaplinga $\mathrm{v}$ razvitii territorial'nyh sistem prirodopol'zovanija (na primere Krasnodarskogo kraja)] // Modern economy: problems and decisions [Sovremennaja jekonomika: problemy i reshenija], 2015, v. 12, p. 63-73.

[4] Bobylev S.N. Sustainable development: methodology and measurement methods [Ustojchivoe razvitie: metodologija i metodiki izmerenija] // S.N. Bobylev, N.V. Zubarevich, S.V. Solov'eva, Yu.S. Vlasov. M.: Jeconomika, 2011.358 p.

[5] Akulov A.O. The decoupling effect in the industrial region (on the example of Kemerovo region) [Jeffekt dekaplinga $\mathrm{v}$ industrial'nom regione (na primere Kemerovskoj oblasti)] // Economical and social changes: facts, tendencies, forecast [Jekonomicheskie i social'nye peremeny: fakty, tendencii, prognoz]. 2013. №4 (28), p.177-185.

[6] Shkiperova G.T. Analysis and modeling of the relationship between economic growth and environmental quality (on the example of Republic of Karelia) [Analiz i modelirovanie vzaimosvjazi mezhdu jekonomicheskim rostom i kachestvom okruzhajushhej sredy (na primere Respubliki Karelija)] // Economical analisys: theory and practice [Jekonomicheskij analiz: teorija i praktika]. 2014. № 43 (394), p. 41-49.

[7] Yu Y., Zhou L., Zhou W., Ren H., Kharrazi A., Ma T., Zhu B. Decoupling environmental pressure from economic growth on city level: the case study of Chongqing in China // Ecological Indicators, 37 (2014). P. 81-89.

[8] Towards sustainable development of Russia. Green economy and modernisation. Ecological-economical principles of sustainable development [Na puti $\mathrm{k}$ ustojchivomu razvitiju Rossii. «Zelenaja jekonomika i modernizacija. Jekologo-jekonomicheskie osnovy ustojchivogo razvitija] / Ed. V.M.Zakharov. M.: Institute of sustainable development, 2012. $90 \mathrm{p}$.

[9] Bobylev S.N., Minakov V.S., Solov'eva S.V., Tret'jakov V.V. Economic environmental index of Russian regions [Jekologo-jekonomicheskij indeks regionov RF]. M., WWF Russia, RIA Novosti. 2012. 147 p.

[10] Ecological footprint of the Russian regions - 2016 [Jekologicheskj sled sub\#ektov Rossijskoj Federacii] / Ed. P. A. Boev и D.L. Burenko. M.: WWF Russia, 2016. 112 p.

[11] Report on the human development in the Russian Federation in 2016 [Doklad o chelovecheskom razvitii v Rossijskoj Federacii za 2016 god] / Eds. S. N. Bobylev and L.M. Grigor'ev. M.: Analytical center for the Government of the Russian Federation, 2016. 298 p.

[12] UNEP's Green Economy Initiative (GEI). Official web-site of the United Nations Environment Program. Режим доступа: https://www.unep.org/greeneconomy/ Дата обращения: 10.11.2017

[13] Federal state statistics service. Regions of Russia. Socio-economic indicators in 2016. Gross regional product [Federal'naja sluzhba gosudarstvennoj statistiki. Regiony Rossii. Social'no-jekonomicheskie pokazateli - 2016. Valovoj regional'nyj produkt]. Режим доступа: http://www.gks.ru/bgd/regl/b16_14p/Main.htm Дата обращения: 08.12.2017

[14] State report on the state of natural resources and environmental protection of the Republic of Tatarstan (2011 and 2016). [Gosudarstvennyj doklad o sostojanii prirodnyh resursov i ob ohrane okruzhajushhej sredy Respubliki Tatarstan (za 2011 i 2016 gg.)]. Official website of the Ministry of natural resources and environment of the Republic of Tatarstan Режим доступа: http://eco.tatarstan.ru/gosdoklad.htm Дата обращения: 12.11.2017

[15] The Republic of Tatarstan 2016. Statistical Handbook. Territorial body of Federal state statistics service in the Republic of Tatarstan. [Respublika Tatarstan 2016. Statisticheskij spravochnik. Territorial'nyj organ Federal'noj sluzhby gosudarstvennoj statistiki po Respublike Tatarstan]. Kazan, $2016 . \quad$ Режим доступа: http://tatstat.gks.ru/wps/wcm/connect/rosstat_ts/tatstat/ resources/76514880443b4aa3ab78ef20d5236cbc/Стат+справочник, +20 16+.pdf Дата обращения: 28.09.2017

[16] The portal of municipalities of the Republic of Tatarstan [Portal municipal'nyh obrazovanij Respubliki Tatarstan]. Режим доступа: http://msu.tatarstan.ru/rus/mregions.htm Дата обращения: 21.10.2017

[17] Pakina A.A., Tul'skaya N.I. Ecological and economic aspects of sustainable development measurement at the regional level [Jekologojekonomicheskie aspekty izmerenija ustojchivosti razvitija na regional'nom urovne] // Environmental management: traditions and innovations [Racional'noe prirodopol'zovanie: tradicii i innovacii]. Proceedings of the II International conference /Ed. M.V. Slipenchuk. M.: KDU Publisher, 2017. P. 263-267.

[18] Tukker, A., Bulavskaya, T., Giljum, S., de Koning, A., Lutter, S., Simas, M., Stadler, K., Wood, R. 2014. The Global Resource Footprint of Nations. Carbon, water, land and materials embodied in trade and final $\begin{array}{llll}\text { consumption } & \text { calculated with } & \text { EXIOBASE } & \text { 2.1. }\end{array}$ Leiden/Delft/Vienna/Trondheim. 72 p. 